\title{
Community Adherence Towards COVID-19 Preventive Health Messages in Somalia
}

\author{
Gallad Dahir Hassan, 1, *, Omar Dahir 2, *, Mohamed Hussein Adam ${ }^{3,}$, Abdiwahab Hassan ${ }^{4, \text {, }}$ \\ Jamal Hassan Ofle ${ }^{5, *}$, Abdulkadir Mohamed Muse , * $^{\text {, }}$ \\ ${ }^{1}$ Department of Public Health, College of Medicine and Health Science, Jamhuriya University of Science and Technology, Mogadishu \\ Somalia \\ ${ }^{2}$ Department of Public Health, College of Medicine and Health Science, Zamzam University of Science and Technology, Mogadishu, \\ Somalia \\ ${ }^{3}$ Department of Public Health, College of Medicine and Health Science, Simad University, Mogadishu, Somalia \\ ${ }^{4}$ Somali Public Health Association (SOPHA), Mogadishu, Somalia \\ ${ }^{5}$ Department of Public Health, College of Medicine and Health Science, University of Somalia, Mogadishu, Somalia \\ ${ }^{6}$ Somali Institute for Development Research and Analysis (SIDRA), Garowe, Puntland, Somalia
}

Email address:

galladph@gmail.com (G. D. Hassan), omarshaani@gmail.com (O. Dahir), ganowyare@gmail.com (M. H. Adam), abdiwahab49@gmail.com (A. Hassan),coofle10@gmail.com (J. H. Ofle), abdukadirmusse09@gmail.com (A. M. Muse)

${ }^{*}$ Corresponding author

\section{To cite this article:}

Gallad Dahir Hassan, Omar Dahir, Mohamed Hussein Adam, Abdiwahab Hassan, Jamal Hassan Ofle, Abdulkadir Mohamed Muse. Community Adherence Towards COVID-19 Preventive Health Messages in Somalia. European Journal of Preventive Medicine.

Vol. 9, No. 1, 2021, pp. 1-7. doi: 10.11648/j.ejpm.20210901.11

Received: December 4, 2020; Accepted: December 11, 2020; Published: January 4, 2021

\begin{abstract}
Background: The coronavirus infection was first reported from Wuhan province, China then it spread becoming a pandemic reaching everywhere in the world. As of the time of writing this article (30th July 2020), the coronavirus pandemic resulted in over 16 million cases and over 650 thousand deaths worldwide. Objective: The objectives of this study was to evaluate community knowledge and practice to COVID-19 preventive measures. Methods: The study was community based cross sectional study design and target population were Somali adults $(\geq 18$ years of age) living in Somalia and using social media, voluntarily accepted to respond the questionnaire after giving short introductory text as informed consent. The data collection technique was online Google Forms, closed ended questionnaire and number of participants in the study was 526 subjects and selected through convenient non-probability sampling technique. Data were analyzed using SPSS. The data frequency and percentage were presented and also bivariate and multivariate analyses were conducted. Results: Among the respondents; $54.4 \%$ were male while $45.6 \%$ were male and in general, their age bracket of 15-25 had the highest percentage of $65.8 \%$ followed by the age bracket of 26-35 with a percentage of 26.8 and those with 36-45 years had a percentage of $3.0 \%$ and finally those above the age of 45 with corona virus information had a percentage of 4.4 . Due to the high level of educational interaction with elite members of the society, those who went to university had better knowledge about the virus with 85.9 percent followed by the secondary level with $7.0 \%$ and then the uneducated with formal education $6.7 \%$ information and the least knowledgeable about the existence of the virus were the primary school who were having a four (4) percentage. About $76 \%$ of participants had a poor level of preventive measures practice toward Covid-19 and $22.4 \%$ had a good level of preventive practice toward Covid-19. 90.7\% of the population also wash their hands frequently after they interact with people and only $9.3 \%$ don't practice hand washing technique. Conclusion: In a nut shell; the study founded that the older the ages of the participants; the less information they have and inversely the higher the education; the more knowledge they have about covid-19. Majority of the participant didn't wear mask when they go outside their home. Closely half of the total population did not give space when they talking to someone else. The study recommends awareness promotion to elder people and health education to illiterate people about covid-19. Also the study suggests to wear mask when people going outside and have one meter space when people talking.
\end{abstract}

Keywords: Knowledge, Practice, COVID19, Health Massage 


\section{Introduction}

Somalia has been without a central government and struggling with prolonged armed conflicts for over 20 years $[1,2]$. The civil war has severely damaged the country's overall health infrastructure, leaving millions without proper healthcare and prone to outbreaks [3]. To Alleviate the recurring health crisis in Somalia, various humanitarian organizations are and have been involved over the years [3] offering basic needs (food, water, shelter) and vital health services despite Somalia's insecurity [3,4]. Although health emergencies and humanitarian crises occur in Somalia from time to time [5], however, Somalia is currently moving away from the "humanitarian emergency" state to a "staterebuilding" state with relative stability [6] which brings a long-awaited hope for Somalia's political and economic endeavors. The coronavirus infection was first reported from Wuhan province, China then it spread becoming a pandemic reaching everywhere in the world [7]. As of the time of writing this article (30th July 2020), the coronavirus pandemic resulted in over 16 million cases and over 650 thousand deaths worldwide [8]. The current global COVID19 pandemic is predicted to have debilitating effects on Africa due to a large number of vulnerable populations, week health infrastructures, an-already limited health services, existing health challenges, and, in some areas, armed conflicts, making the continent a hot spot [7,9]. Somalia is ranked number one among the countries that are more susceptible to become a hot spot in the case of outbreaks and pandemics (such as COVID-19) mainly because of its fragile state [8]. However, in order to reduce the impact of the disease spread, Somalia government has taken control with strict steps to reduce transmission of coronavirus, these includes personal steps include staying home when sick, covering coughs and sneezes with a tissue, washing hands often or using hand sanitizer, community measures include creating physical distance between people in setting where they commonly come in contact with one another (like workplace) and temporally closed school, universities where students, teacher, and staff members come in close contact with one another and lastly canceled large public events. Many risk factors including older age, female gender, children, and existing health issues have been associated with COVID-19 [9]. People's adherence to health messages during outbreaks and pandemics is very important in limiting the further spread of the disease and it is greatly affected by their prior knowledge and perception of the issue [10]. Communication during this pandemic is an issue in Low- and Middle-Income Countries (LMICs) [11]. Therefore, providing the right information and preventing misinformation posted on social media are some of the challenges faced $[11,12]$. The Somali Ministry of Health has added a very informative COVID-19 page to its website [13] and a 'WhatsApp Coronavirus Information Hub' service. The page provides information including the total number of confirmed cases, active cases, recovered cases, and the number of deaths, number of cases by daily, and number of cases per State [13]. In addition to the COVID-19 pandemic, Somalia also faces floods and drought making the situation in Somalia more disastrous (14). The World Bank has approved \$137.5 million in response to the 'triple threat' in Somalia [14, 15].

Furthermore, The World Health Organization has launched three COVID-19 test labs in three major cities in Somalia (Mogadishu, Garowe, and Hargeisa) [14]. Moreover, the WHO Somalia office has also trained health workers on how to use Personal Protective Equipment's (PPE) and produced translated COVID-19 health messages in Somali [14]. This study was conducted via social media after the first case of COVID-19 in Somalia was confirmed with the purpose of assessing how prepared and knowledgeable the people were considering the severity of the pandemic. Peoples' knowledge and practices during this pandemic and adherence to the health messages provided by the local authorities and the international organizations is a cornerstone in the course, depth of impact, the success of mitigation efforts, and the future of COVID-19 in Somalia.

\section{Methods and Materials}

This study was community based cross-sectional design to assess community knowledge and practice to covid-19 preventive measures from recognized local health authorities. Since, the first cases of the COVID-19 confirmed in Somalia on March 16, 2020 the government declared the country lockdown on April 2, 2020. The target population were Somali adults ( $\geq 18$ years of age) living in Somalia using social media and accepted voluntarily to respond to the questionnaire after giving a short introductory text as informed consent. Total number of participants in the study were 526 from different regions in Somalia and selected through convenient Nonprobability sampling technique. Data were collected through online Google Form, closed ended, self-administered questionnaire between April to June 2020 and distributed through social media via posting Facebook pages and whatsup groups. The questionnaire consists of three sections those are demographic characteristics, knowledge of Covid-19 and practice to preventive measures.

\subsection{Statistical Analysis}

Data were retrieved from Google drive through excel. This was followed by data cleaning and analysis using the statistical package for the social sciences (SPSS), version 23. Descriptive statistics such as frequency and percentage distributions were used to present the analyzed quantitative data. The independent variables were categorized to analyze the association between each independent variables and outcome variable using a bivariate analysis. Variables with a P-value of $<0.05$ in the multivariate analysis were considered to be significant.

\subsection{Questionnaire Scoring Scales}

An online platform form was conducted using structured 
questionnaire to collect information on community knowledge and adherence to COVID-19 health education messages from health authority. The questionnaire was structured into three distinctive sections. Section one was to collect information on respondents' demographic characteristics such as gender, age, level of education and occupational status. Section two and three were concerned with information on the respondents' knowledge and practice of COVID-19 respectively. Answers were graded on a scale of two, with 1 indicating "yes or correct" and 0 "no or incorrect". The section of questionnaire dealing with respondents' knowledge comprised 5 close-ended questions with two possible answers; "yes" and "No". These questions specifically dealt with respondents' preventive knowledge of COVID-19.. A scale ranging between 0 and 5 (representing the total number of questions on preventive knowledge of COVID-19 was used to evaluate the overall knowledge of respondents. Respondents that obtained total score $\leq 3$ points were considered to have "insufficient" knowledge and those that had scores $\geq 4$ points $(\geq 80 \%$ accuracy) were considered to have "good" knowledge of Covid-19. In section three, which dealt with preventive practices of COVID-19, the good preventive practices of respondents were assessed and evaluated based on selfreporting of personal practices. The section had 11 questions with two possible responses: "yes", and "no". Each correct practice reported scored one (1) point. For evaluation, a score $\geq 6$ points ( $\geq 55 \%$ accuracy) by Answers were graded on a scale of two with 1 indicating "yes or correct" and 0 "no or incorrect". The section of questionnaire dealing with respondents' knowledge comprised 5 close-ended questions with two possible answers; "yes" and "No". These questions specifically dealt with respondents' preventive knowledge of COVID-19. an individual respondent was considered as having "good" knowledge of Covid-19.

\section{Results}

\subsection{Demographic Characteristics of Respondents}

Among the respondents who were questioned in the demographic region of focus were male, $54.4 \%$, followed by female with $45.6 \%$ and in general, their age bracket of $15-25$ had the highest percentage of $65.8 \%$ followed by the age bracket of 26-35 with a percentage of 26.8 and those with 3645 years had a percentage of $3.0 \%$ and finally those above the age of 45 with corona virus information had a percentage of 4.4. Due to the high level of educational interaction with elite members of the society, those who went to university had better knowledge about the virus with 85.9 percent followed by the secondary level with $7.0 \%$ and then the uneducated with formal education $6.7 \%$ information and the least knowledgeable about the existence of the virus were the primary school who were having a four (4) percentage. The unemployed had the minimum knowledge about the virus with $8.9 \%$ followed by in ascending order by self-employed with $31.0 \%$ and the highest were the people who had occupation in public institutions with $60.1 \%$.
Table 1. Demographic characteristics.

\begin{tabular}{llll}
\hline Variables & Category & $\mathbf{( N = 5 2 6 )}$ & $\mathbf{\%}$ \\
\hline \multirow{2}{*}{ Gender } & Male & 286 & $54.4 \%$ \\
& Female & 240 & $45.6 \%$ \\
Age & $15-25$ & 346 & $65.8 \%$ \\
& $26-35$ & 141 & $26.8 \%$ \\
& $36-45$ & 16 & $3.0 \%$ \\
Education & 46 above & 23 & $4.4 \%$ \\
& Informal education & 37 & $7.0 \%$ \\
& Primary & 2 & $0.4 \%$ \\
& Secondary & 35 & $6.7 \%$ \\
& University level & 452 & $85.0 \%$ \\
& Unemployment & 47 & $8.9 \%$ \\
\hline
\end{tabular}

\subsection{Knowledge of Respondents Towards COVID-19}

In current study when asked if they heard COVID-19 before $82.3 \%$ have confirmed they heard it before. out of this, radio was the fastest method of communication that they found about the virus with $64.8 \%$, followed by the use of social media with $8.7 \%$ and TV users had the least percentage of 6.7 . while $17.7 \%$ never heard about the virus and had no previous information. $17.7 \%$ could not figure out where they first heard it from and therefore could not answer. $94.9 \%$ believed the existence of the virus in Somalia while only $5.1 \%$ had no faith in the existence of the prevalence of the virus in Somalia. The morbidity rate of the virus was popular among people in Somalia as $75.5 \%$ of the population confirmed that they know people who are sick because of the disease and $24.5 \%$ had no idea and could not verify if they saw a Covid 19 patient The wide range public awareness of the virus had reached almost everyone in Somalia as $96.4 \%$ have heard or watched or read the health education-messages about how to prevent and manage covid-19 and only $3.6 \%$ were not aware of the ongoing awareness.

Table 2. Knowledge of respondents towards COVID-19 (526).

\begin{tabular}{llll}
\hline Variable & Category & N & \% \\
\hline Have you heard Covid19 before & Yes & 433 & $82.3 \%$ \\
& No & 93 & $17.7 \%$ \\
& Radio & 341 & $64.8 \%$ \\
& TV & 35 & $6.7 \%$ \\
Where did you hear it first & Social media & 46 & $8.7 \%$ \\
& Friends/ relatives & 11 & $2.1 \%$ \\
& Not answered & 93 & $17.7 \%$ \\
Do you believe Covid19 exists in & Yes & 499 & $94.9 \%$ \\
Somalia & No & 27 & $5.1 \%$ \\
Do you know morbidity rate of Covid & Yes & 397 & $75.5 \%$ \\
19 in Somalia & No & 129 & $24.5 \%$ \\
$\begin{array}{l}\text { Do you hear or watch or read health } \\
\text { education messages about how to }\end{array}$ & Yes & 507 & $96.4 \%$ \\
prevent and control Covid19 & No & 19 & $3.6 \%$ \\
\hline
\end{tabular}




\subsection{Preventive Practice of Respondents towards COVID-19}

Due to the lack of strict policies from the government on people movement in Somalia $61.6 \%$ of the population go outside their homes frequently for work or other purposes and $29.5 \%$ stay at home. Only $8.9 \%$ could not answer. Regarding those who go outside, only $12.5 \%$ wear mask and a total of $78.5 \%$ don't wear masks and $8.9 \%$ opted not to answer. The interaction between people and the greetings among them also played an important role on how the virus can spread among people when asked about if they hug each other when they meet with friends or relatives they miss a lot, only $24.9 \%$ said yes and $75.1 \%$ confirmed that they don't hug each other. $90.7 \%$ of the population also wash their hands frequently after they interact with people and only $9.3 \%$ don't practice hand washing technique. Since the outbreak of the virus covid-19 in Somalia, symptoms such as headache, cough and fever were very rear among the people as $79.7 \%$ said they didn't felt such symptoms and only $20.3 \%$ had symptoms such as headache and fever. Among those who felt the symptoms only 5.5\% did not stayed at home for their safety and the safety of their community. $14.8 \%$ managed to stay at home and a huge number of $79.7 \%$ could not answer. Those who visited a covid-19 patient in the last few years since its outbreak, only $13.5 \%$ confirmed that they did visited a sick person and $86.5 \%$ have not visited. Keeping distance among people was almost a tie for those who give space between them when talking to each other. $59.9 \%$ and $48.1 \%$ were the results for those who keep distance and those who don't keep distance between them respectively. People who go to funerals of someone who died for covid-19 reason or even having the symptoms of fever, cough and shortness of breath were very few $9.7 \%$ compared to those who do not visited with a percentage of $90.3 \%$. when asked those who go to the funerals if they take precautions such as wearing masks and gloves a large number of $90.3 \%$ hesitated to answer and $5.7 \%$ said they do take precautions and only $4 \%$ go to funerals without masks or gloves. In table 4 in this inquire the knowledge score mean of females was slightly higher than the one of males (4.51 and 4.4), respectively). There was no statistically significant difference between males and females as confirmed by (t-test $=0.221$ " -0.21 $0.165 ", \mathrm{p}=0.83$ ). Respondents aged $36-45$ had knowledge mean score (4.8) greater than the rest of the groups.. By conducting a One Way ANOVA test, the value of $\mathrm{F}$ is 2.3, which reaches significance with a p-value less than 0.049 (which is less than the .05 alpha level). This means there is a statistically significant difference between the means of the different age groups.

Table 3. Preventive practice of respondents towards COVID-19.

\begin{tabular}{|c|c|c|c|}
\hline Variables & Category & $\mathbf{N}$ & $\%$ \\
\hline \multirow[b]{2}{*}{ Do you go outside your home frequently for work or other purposes } & Yes & 324 & $61.6 \%$ \\
\hline & No & 155 & $29.5 \%$ \\
\hline \multirow{3}{*}{ If yes in the above questions, do you wear a mask } & Yes & 66 & $12.5 \%$ \\
\hline & No & 413 & $78.5 \%$ \\
\hline & Not answered & 47 & $8.9 \%$ \\
\hline \multirow{2}{*}{ Do you shake hands with people when you greetings } & Yes & 175 & $33.3 \%$ \\
\hline & No & 351 & $66.7 \%$ \\
\hline \multirow{2}{*}{ Do you hug when you meet friends or relatives you miss a lot } & Yes & 131 & $24.9 \%$ \\
\hline & No & 395 & $75.1 \%$ \\
\hline \multirow{2}{*}{ Do you wash your hands frequently to prevent covid19 } & Yes & 477 & $90.7 \%$ \\
\hline & No & 49 & $9.3 \%$ \\
\hline Since the Covid19 outbreak in Somalia; did you feel headache, cough and fever? & No & 419 & $79.7 \%$ \\
\hline \multirow{3}{*}{$\begin{array}{l}\text { If you respond yes in the above questions; did you stay at home for the safety of you and the } \\
\text { community }\end{array}$} & Yes & 78 & $14.8 \%$ \\
\hline & No & 29 & $5.5 \%$ \\
\hline & No answered & 419 & $79.7 \%$ \\
\hline \multirow{2}{*}{ Last few weeks, since the outbreak of covid19, have you visited sick person } & Yes & 71 & $13.5 \%$ \\
\hline & No & 455 & $86.5 \%$ \\
\hline \multirow{2}{*}{ When you meet and talking someone, did you give space between you and two } & Yes & 273 & $51.9 \%$ \\
\hline & No & 51.9 & $48.1 \%$ \\
\hline \multirow{2}{*}{$\begin{array}{l}\text { Did you go funeral of someone dead for covid } 19 \text { or even have the symptoms of fever, cough } \\
\text { and shortness of breath }\end{array}$} & Yes & 51 & $9.7 \%$ \\
\hline & No & 475 & $90.3 \%$ \\
\hline \multirow[b]{2}{*}{ If yes did you take precaution like wearing mask and gloves } & Yes & 30 & $5.7 \%$ \\
\hline & No & 21 & $4 \%$ \\
\hline
\end{tabular}


Table 4. Mean and standard deviation of knowledge score.

\begin{tabular}{|c|c|c|c|c|c|c|c|}
\hline & & $\mathbf{N}$ & $\%$ & Knowledge score $($ mean \pm SD) & T-test $(95 \% \mathrm{CI})$ & ANOVA $(95 \%$ CI) & P-Value \\
\hline \multirow{2}{*}{ Gender } & Male & 286 & 54.4 & $4.51(0.743)$ & \multirow{2}{*}{$1.6(-0.03-0.25)$} & \multirow{2}{*}{ N/A } & \multirow{2}{*}{0.11} \\
\hline & Female & 240 & 45.6 & $4.40(0.857)$ & & & \\
\hline \multirow{4}{*}{ Age } & $15-25$ & 346 & 65.8 & $4.44(0.81)$ & \multirow{5}{*}{ N/A } & \multirow{5}{*}{2.3} & \multirow{5}{*}{0.049} \\
\hline & $26-35$ & 141 & 26.8 & $4.51(0.723)$ & & & \\
\hline & $36-45$ & 16 & 3 & $4.81(0.40)$ & & & \\
\hline & 46 and above & 23 & 4.4 & $4.13(1.1)$ & & & \\
\hline \multirow{4}{*}{$\begin{array}{l}\text { Educational } \\
\text { Level }\end{array}$} & Informal Education & 37 & 7 & $3.86(0.976)$ & & & \\
\hline & Primary & 2 & 0.4 & $4.5(7.07)$ & \multirow{3}{*}{ N/A } & \multirow{3}{*}{8.1} & \multirow{3}{*}{0.0001} \\
\hline & Secondary & 35 & 6.7 & $4.34(0.938)$ & & & \\
\hline & University and above & 452 & 85.9 & $4.51(4.46)$ & & & \\
\hline \multirow{4}{*}{ Occupation } & Un-employed & 47 & 8.9 & $4.49(0.88)$ & \multirow{4}{*}{ N/A } & \multirow{4}{*}{0.529} & \multirow{4}{*}{0.59} \\
\hline & Self-employed & 163 & 31 & $4.5(0.73)$ & & & \\
\hline & Public Institution & 316 & 60 & $4.43(0.798)$ & & & \\
\hline & Private Institution & 0 & 0 & N/A & & & \\
\hline
\end{tabular}

Table 5. Mean and standard deviation of preventive practice score.

\begin{tabular}{|c|c|c|c|c|c|c|c|}
\hline & & $\mathbf{N}$ & $\%$ & Practice score (mean \pm SD) & T-test $(95 \% \mathrm{CI})$ & ANOVA (95\% CI) & P-Value \\
\hline \multirow{2}{*}{ Gender } & Male & 286 & 54.4 & $4.89(1.12)$ & \multirow{2}{*}{$0.221(-.21-.165)$} & \multirow{2}{*}{ N/A } & \multirow{2}{*}{0.83} \\
\hline & Female & 240 & 45.6 & $4.91(1.2)$ & & & \\
\hline \multirow{4}{*}{ Age } & $15-25$ & 346 & 65.8 & $4.81(1.1)$ & \multirow{4}{*}{ N/A } & \multirow{4}{*}{3.14} & \multirow{4}{*}{0.025} \\
\hline & $26-35$ & 141 & 26.8 & $5(0.89)$ & & & \\
\hline & $36-45$ & 16 & 3 & $5.38(0.89)$ & & & \\
\hline & 46 and above & 23 & 4.4 & $5.2(0.89)$ & & & \\
\hline \multirow{4}{*}{$\begin{array}{l}\text { Educational } \\
\text { Level }\end{array}$} & Informal Education & 37 & 7 & $4.95(1.2)$ & \multirow{4}{*}{ N/A } & \multirow{4}{*}{0.48} & \multirow{4}{*}{0.7} \\
\hline & Primary & 2 & 0.4 & $4.5(0.7)$ & & & \\
\hline & Secondary & 35 & 6.7 & $4.7(1.2)$ & & & \\
\hline & University and above & 452 & 85.9 & $4.9(1)$ & & & \\
\hline \multirow{4}{*}{ Occupation } & Un-employed & 47 & 8.9 & $5.2(1.2)$ & \multirow{4}{*}{ N/A } & \multirow{4}{*}{1.77} & \multirow{4}{*}{0.172} \\
\hline & Self-employed & 163 & 31 & $4.9(0.7)$ & & & \\
\hline & Public Institution & 316 & 60 & $4.8(1.2)$ & & & \\
\hline & Private Institution & 0 & 0 & N/A & & & \\
\hline
\end{tabular}

In this inquire the preventive practice average score of females was slightly higher than the one of males 4.91 and (4.89, respectively). There was no statistically significant difference between groups as confirmed by t-Test $(0.221$ ($0.21-0.165) \mathrm{p}=0.83)$. Respondents aged $36-45$ had preventive practice mean score (5.38) greater than the rest of the groups. By conducting a One Way ANOVA test, the value of $F$ is 3.13 , which reaches significance with a pvalue of .025 (which is less than the .05 alpha level). This means there is a statistically significant difference between the means of the different levels of the education variable. According to the educational level, participant with educational level of university and above had a better knowledge mean score (4.51) as compared to their counterparts. Interestingly, the participant with informal education had a preventive practice score (4.95) better than their counterparts. Finally, the respondents with selfemployed were slightly had a knowledge mean score (4.5) greater than their counterparts. This study assessed whether the study participants' different occupations produce a difference in the mean scores of preventive practices. The study revealed that there was no statistically significant difference between the occupational groups in the mean score of preventive practice as demonstrated by one-way
ANOVA ( $\mathrm{F}=1.77, \mathrm{p}=.172)$. Similarly, after conducting a Turkey post hoc test, we can see from the table \# that there is no statistically significant difference in the mean score of preventive practice among the three groups $(\mathrm{P}=0.46$ between un-employee and Public institution and $(\mathrm{p}=0.68)$ between the self-employee and un-employee groups and finally $(\mathrm{P}=0.174)$ between the public institution and selfemployee.

\section{Discussion}

Since the corona virus was declared a pandemic by WHO across the globe, many countries have started public awareness on how to prevent the spread of the corona virus which include social distancing, avoiding public gatherings and the use of masks, Somalia, spearheaded by the ministry of health did managed to do the awareness by using different kinds of communications but still it has not reached many people compared to other countries, a good example is that, very few number of female individuals were aware of the existence of the virus in Somalia compared to other countries in Africa such as Kenya [16]. Female population is more than that of male population in Somalia and in terms of the educational level it is estimated that men are mostly the educated and have 
reached higher educational level than women, this literacy comparison made men to have more information about the existence of corona virus than women in Somalia [17]. Compared to the female population in other countries such as Kenya where female child education had been the priority for a long time. Also the elderly people in Somalia as well as the unemployed sector of the population and those who are in the villages or small towns had little awareness about the virus compared to the study that was done in Kenya [18] that was targeting these mentioned populations. This can be associated with the fact that, in Kenya, the elderly people have access to the modern technology and can get first-hand information are mainly tuned to news and social media unlike in Somalia where people who don't live in big cities are mainly pastoralists and move from one place to another. Due to cultural behavior and believes, there are so many people in Somalia who don't believe the existence of the covid-19 virus despite the effort and continuous awareness given by the ministry of health. These cultural believe has reduced the mass testing of the covid-19 virus and has increased the morbidity rate of covid-19 in Somalia compared to the study that was done in Rwanda [19] where people follow the instructions given by their ministry of health. The mass testing of covid-19 in Somalia was never successful unlike other countries in the region who are still doing mass testing and sharing the data but in Somalia it is hindered by the fact that the government don't control majority of the country and also it does not have the adequate health personals who can carry out testing across the country. Wearing of masks and avoiding public gatherings is one of the best ways suggested by WHO to prevent the disease from spreading. This study shows that $78 \%$ of the people in Somalia don't wear masks and they also don't practice social distancing, totally opposite study was carried out by health professionals in countries such as Uganda [20, 21] and Ethiopia which indicates that $80 \%$ of the population don't shake hands and also don't go outside without wearing masks. Visiting the sick and following funerals is the norm in Somalia without differentiating whether the sick person has symptoms of covid-19 such as fever, cough and shortness of breath or even if the person have died because of covid-19, such practices are not allowed in many countries like Saudi because there level of preventive practice towards covid-19 is extremely good compared to Somalia.

\section{Conclusion}

In a nut shell, the study founded that the older the ages of the participants; the less information they have and inversely the higher the education; the more knowledge they have about covid-19.

Majority of the participant didn't wear mask when they go outside their home. Closely half of the total population did not give space when they talking to someone else. The study recommends awareness promotion to elder people and health education to illiterate people about covid-19. Also the study suggest to health authorities to regulate wearing face mask when people going outside and have enough space when people gathering. Further research on community perception towards face mask due to covid-19 prevention was recommended.

\section{Strength and Limitation of This Study}

The strength of this study was the first study to evaluate community knowledge and adherence to COVID-19 health education messages from health authority and the limitation for this study was data collected through online via social media and any person with have access of social media and internet can participate in the study and this research cannot represent at whole population.

\section{Abbreviations}

COVID19: coronavirus

LMICs: Law to middle income countries

PPE: Personal protective equipment

SPSS: statistical package for social science

WHO: world health organization

\section{Data Availability}

The data used to support the findings of this study are available from the corresponding author upon reasonable request.

\section{Conflict of Interest Statement}

The authors declare that they have no competing interests.

\section{Authors' Contributions}

All authors have contributed equally to this work. All authors read and approved the final manuscript.

\section{Acknowledgements}

Special thanks goes to Somali Public Health Association (SOPHA) due to support during data collection process and all participants who took part in the study.

\section{References}

[1] Elmi AA, Barise DA. The Somali Conflict: Root causes, obstacles, and peace-building strategies. Afr Secur Rev. 2006 Jan 1; 15 (1): 32-54.

[2] Zeid AA, Cochran JJ. Understanding the crisis in Somalia. Significance. 2014; 11 (1): 4-9.

[3] Warsame A, Handuleh J, Patel P. Prioritization in Somali health system strengthening: a qualitative study. Int Health. 2016 May 1; 8 (3): 204-10.

[4] Cabrol J-C. War, drought, malnutrition, measles--a report from Somalia. N Engl J Med. 2011 Nov 17; 365 (20): 18568. 
[5] Conway G, Watson P. In Somalia, seeking to ensure drought never again turns into famine [Internet]. UNDP. [cited 2020 Jul 21]. Available from: https:/www.undp.org/content/undp/en/home/blog/2018/insomalia--humanitarian-and-development-solutions-seek-toensur.html.

[6] Mdinilla A, Sheferaw LT, Veron P. Think local. Governance, humanitarian aid, development and peacebuilding in Somalia. ECDPM Pap [Internet]. 2019 Mar [cited 2020 Jul 21]; Available from: https://ecdpm.org/publications/think-localbridging-between-humanitarian-aid-developmentpeacebuilding-somalia/.

[7] Ferguson N, Laydon D, Nedjati Gilani G, Imai N, Ainslie K, Baguelin M, et al. Report 9: Impact of non-pharmaceutical interventions (NPIs) to reduce COVID19 mortality and healthcare demand [Internet]. 20. 2020 Mar [cited 2020 Jul 30]. Available from: http://spiral.imperial.ac.uk/handle/10044/1/77482.

[8] WHO Coronavirus Disease (COVID-19) Dashboard [Internet]. [cited 2020 Jul 30]. Available from: https://covid19. who.int.

[9] Liu T, Liang W, Zhong H, He J, Chen Z, He G, et al. Risk factors associated with COVID-19 infection: a retrospective cohort study based on contacts tracing. Emerg Microbes Infect 2020 Jan 1; 9 (1): 1546-53.

[10] Zhong B-L, Luo W, Li H-M, Zhang Q-Q, Liu X-G, Li W-T, et al. Knowledge, attitudes, and practices towards COVID-19 among Chinese residents during the rapid rise period of the COVID-19 outbreak: a quick online cross-sectional survey. Int J Biol Sci. 2020 Mar 15; 16 (10): 1745-52.

[11] Bong C-L, Brasher C, Chikumba E, McDougall R, MellinOlsen J, Enright A. The COVID-19 Pandemic: Effects on Low- and Middle-Income Countries. Anesth Analg [Internet]. 2020 Apr 20 [cited 2020 Jul 24]; Available from: https://www.ncbi.nlm.nih.gov/pmc/articles/PMC7173081/.

[12] Lau LL, Hung N, Go DJ, Ferma J, Choi M, Dodd W, et al. Knowledge, attitudes and practices of COVID-19 among income-poor households in the Philippines: A cross-sectional study. J Glob Health [Internet]. [cited 2020 Jul 24]; 10 (1). Available from: https://www.ncbi.nlm.nih.gov/pmc/articles/PMC7294392/.
[13] COVID-19 Situational Update [Internet]. Ministry of Health Somalia. [cited 2020 Jul 21]. Available from: https://moh.gov.so/en/covid19/.

[14] COVID-19, locusts, flooding: WHO and triple threat in Somalia [Internet]. World Health Organization. [cited $2020 \mathrm{Jul}$ 22]. Available from: https://www.who.int/news-room/featurestories/detail/covid-19-locusts-flooding-who-and-triple-threatin-somalia.

[15] World Bank Approves \$137.5 Million for Somalia's Response to COVID-19, Floods, and Drought [Internet]. Press Release. [cited 2020 Jul 22]. Available from: https://www.worldbank.org/en/news/pressrelease/2020/05/15/world-bank-approves-137-5-million-forsomalias-response-to-covid-19-floods-and-drought.

[16] ustrian K, Pinchoff J, Tidwell JB, White C, Abuya T, Kangwana B, et al. COVID-19 Related Knowledge, Attitudes, Practices and Needs of Households in Informal Settlements in Nairobi, Kenya. SSRN Electron J. 2020; (April): 1-21.

[17] Quaife M, Van Zandvoort K, Gimma A, Shah K, McCreesh N, Prem K, et al. The impact of COVID-19 control measures on social contacts and transmission in Kenyan informal settlements. BMC Med. 2020; 18 (1): 1-11.

[18] Council P. Kenya: COVID-19 knowledge, attitudes \& practices. 2020; (April): 17-9.

[19] Mutesa L, Ndishimye P, Butera Y, Souopgui J, Uwineza A, Rutayisire R, et al. A strategy for finding people infected with SARS-CoV-2: optimizing pooled testing at low prevalence. 2020;(April). Available from: http://arxiv.org/abs/2004.14934.

[20] Ssebuufu R, Sikakulya F, Binezero SM, Wasingya L, Nganza $\mathrm{S}$, Ibrahim B, et al. Awareness, knowledge, attitude and practice towards measures for prevention of the spread of COVID-19 in the Ugandans: A nationwide online crosssectional Survey. 2020; (July).

[21] Alsofayan YM, Althunayyan SM, Khan AA, Hakawi AM, Assiri AM. Clinical characteristics of COVID-19 in Saudi Arabia: A national retrospective study. J Infect Public Health [Internet]. 2020; 13 (7): 920-5. Available from: https://doi.org/10.1016/j.jiph.2020.05.026. 